\title{
Effects of surgical castration, immunocastration and homeopathy on the performance, carcass characteristics and behaviour of feedlot- finished crossbred bulls
}

\section{Efeitos da castração cirúrgica, imunocastração e homeopatia sobre o desempenho, características de carcaça e comportamento de bovinos machos cruzados terminados em confinamento}

\author{
Vantuil Moreira de Freitas ${ }^{1}$; Karen Martins Leão ${ }^{2}$; Francisco Ribeiro de Araujo \\ Neto $^{2}$; Thaisa Campos Marques ${ }^{3 *}$; Rafael Moraes Ferreira ${ }^{4}$; \\ Lázaro Leonardo Franco Garcia ${ }^{4}$; Eunivânio Barbosa de Oliveira ${ }^{4}$
}

\begin{abstract}
The aim of this study was to evaluate total weight gain, carcass yield, rib-eye area, marbling, subcutaneous fat thickness, frequencies of mounting, excitement, dominance behaviour and serum testosterone concentration in feedlot-finished non-castrated bulls, surgically castrated bulls, immunocastrated bulls and bulls treated with homeopathy. The study involved 52 calves, Holstein-Zebu, $20 \pm 3$ months old, in a completely randomised design divided into four treatments of 13 animals: non-castrated, surgically castrated, immunocastrated and non-castrated with homeopathy. Analysis of variance was performed, and the Tukey test was applied $(\mathrm{P}<0.05)$. The Pearson correlation coefficient was estimated and principal components analysis was performed. The castrated animals had lower total weight gain and carcass yield than the animals in the remaining treatment groups. The immunocastrated bulls had a greater subcutaneous fat thickness than the non-castrated bulls. The castrated bulls exhibited lower frequencies of mounting, excitement and dominance behaviour than the animals in the remaining treatment groups. Testosterone levels were lower in the castrated animals. Principal components analysis revealed a moderate magnitude and sharpness in the differentiation of the castrated animals. It was concluded that the immunocastrated animals were similar in performance to the non-castrated animals, while the carcass finish characteristics of the immunocastrated animals were similar to the castrated animals. The castrated animals had lower productive performance than the animals in the remaining treatment groups. The homeopathy animals had performance and carcass finish characteristics similar to the non-castrated animals. Homeopathy and immunocastration did not reduce sodomy and dominance behaviours.
\end{abstract}

Key words: Immunological castration, marbling, sodomy, testosterone

1 Discente do Curso de Mestrado em Zootecnia, Instituto Federal de Educação, Ciência e Tecnologia Goiano, Campus Rio Verde, GO, Brasil. E-mail: vantuilelu@uol.com.br

2 Profs. Pesquisadores, Instituto Federal de Educação, Ciência e Tecnologia Goiano, Campus Rio Verde, GO, Brasil. E-mail: karenleao2@yahoo.com.br; netozoo@hotmail.com

3 Discente do Curso de Doutorado em Zootecnia, Universidade Federal de Goiás, UFG, Goiânia, GO, Brasil E-mail: thaisacm@ hotmail.com

4 Discentes do Curso de Graduação em Medicina Veterinária, Universidade de Rio Verde, UniRV, Rio Verde, GO, Brasil. E-mail: rafaelmoraesrv@hotmail.com; leonardogarcia_vet@hotmail.com; eunivanio88@msn.com

* Author for correspondence 


\section{Resumo}

Objetivou-se determinar ganho de peso, rendimento de carcaça, área olho lombo, marmoreio, espessura de gordura subcutânea, frequências de monta, excitação, dominância e concentração sérica de testosterona de bovinos não castrados, castrados cirurgicamente, imunocastrados e tratados com homeopatia terminados em confinamento. Utilizou-se 52 garrotes, 3/4 holandês-zebu, $20 \pm 3$ meses de idade e $303,78 \pm 15,78 \mathrm{Kg}$, distribuídos inteiramente ao acaso em quatro tratamentos de 13 animais: não castrados, castrados cirurgicamente, imunocastrados e não castrados tratados com homeopatia. Fez-se a análise de variância e quando esta foi significativa $(\mathrm{P}<0,05)$, aplicou-se o teste de Tukey. Estimou-se o coeficiente de correlação de Pearson entre as variáveis e realizou a análise de componente principal. Os castrados apresentaram menor ganho de peso e rendimento de carcaça que os demais tratamentos e marmoreio superior aos imunocastrados e tratados com homeopatia. Os imunocastrados obtiveram maior espessura de gordura subcutânea que os não castrados. Os castrados manifestaram menores frequências de monta, excitação e comportamento de dominância que os demais tratamentos. A testosterona foi inferior nos castrados. A análise de componente principal apresentou magnitude moderada e nitidez na diferenciação dos castrados. Conclui-se que os imunocastrados apresentaram desempenho semelhante aos não castrados e acabamento de carcaça semelhante aos castrados e estes obtiveram desempenho produtivo inferior aos demais tratamentos. A homeopatia obteve desempenho e acabamento de carcaça semelhante aos não castrados. A imunocastração não foi eficiente na manutenção de baixos níveis testosterona. A homeopatia e a imunocastração não amenizaram o comportamento de sodomia e dominância.

Palavras-chave: Castração imunológica, marmoreio, sodomia, testosterona

\section{Introduction}

The purpose of castration is to reduce the management problems related to aggressiveness and sexual behaviour because it renders the animals more docile and mitigates sexual conduct such as sodomy. Additionally, castration provides a better carcass finish with a higher percentage of marbling and a greater subcutaneous fat thickness, which is desired by the slaughter house industry because the carcass is protected against the effects of refrigeration, thus avoiding dark meats and meats with depreciative visual aspects (FREITAS et al., 2008).

However, the limitations of the surgical castration technique include the burdens caused by post-operative complications, a lower weight gain and the risk of death, as well as a rising concern with animal welfare among the human population because of the negative perception of castration due to animal pain and suffering (COETZEE et al., 2010).
Therefore, an alternative is immunocastration using a vaccine that stimulates the production of antibodies against the synthesis of gonadotropins anti-gonadotropin-releasing hormone (GnRH) antibodies, which inhibit the liberation of luteinising hormone (LH) and follicle-stimulating hormone (FSH) by the pituitary gland and thus suppress testicular function in males, with a subsequent decrease in the concentration of blood testosterone (ZANELLA et al., 2009).Another alternative to surgical castration is veterinary homeopathy, which is indicated for both the healing and prevention of diseases, the control of stress and the improvement of performance and feed conversion, as well as for controlling the sexual behaviour of sodomy (SOUZA, 2002).

The aim of this study was to evaluate the effect of surgical castration, immunocastration and homeopathic treatment on animal performance, sexual behaviour, carcass characteristics and serum testosterone concentrations in $3 / 4$ Holstein-Zebu feedlot-finished bulls. 


\section{Materials and Methods}

Location, time period, treatments, installations and feeding

This research was approved by the Committee of Ethics in Animal Research of the Federal Institute of Education, Science and Technology of Goiás under the protocol number 09/2012. The experiment was performed in a feedlot in the municipality of Rio Verde, state of Goiás, Brazil, located at latitude $17^{\circ} 46^{\prime} 27,56^{\prime \prime} \mathrm{S}$ and longitude $50^{\circ} 58^{\prime} 55,32^{\prime \prime} \mathrm{W}$, from July 11 to October 03, 2012.

The study involved 52 crossbred male $3 / 4$ Holstein-Zebu calves, $20 \pm 3$ months old, with a $303.78 \pm 15.78 \mathrm{~kg}$ mean initial live weight. The animals were randomly distributed into four treatments of 13 animals each as follows: treatment 1 , non-castrated (intact) bulls; treatment 2 , surgically castrated bulls; treatment 3, immunocastratedbulls; and treatment 4 ,non-castrated bulls treated with homeopathic products.

The feedlot installations consisted of four corrals of 13 animals. Each corral consisted of an earthen ground area $6 \mathrm{~m}$ in length and $35 \mathrm{~m}$ in width, with $0.46 \mathrm{~m}$ of trough per animal and $16.15 \mathrm{~m}^{2}$ of area per animal. After 85 days of confinement, the bulls were slaughtered in a slaughterhouse under the Federal Inspection Service.

The diet was composed of corn silage (25\%), cottonseed (8\%), ground corn (31\%) and sorghum $(30 \%)$, soybean $(3 \%)$, urea $(1 \%)$, mineral and vitamin supplement with the growth promoter virginiamycin (2\%) and water ad libitum. The total diet was calculated to contain $14 \%$ crude protein and $77 \%$ total digestible nutrients. On the first day of confinement, the animals received only corn silage, and from the second day until the tenth day, the diet was adapted via an increase in concentrate and decrease in forage until the proportion of $70 \%$ concentrate and $30 \%$ forage was obtained.

The food leftovers were removed and weighed daily at $7 \mathrm{AM}$, and new food was offered every 2 hours until $5 \mathrm{PM}$; the food quantity provided for each lot was always measured, and the excess or absence of food in the trough was avoided. Every 15 days, the total diet was sampled for the determination of dry matter according to the technique recommended by the Association of Official Analytical Chemists (AOAC, 1995).

\section{Surgical castration, immunocastration and} homeopathic treatment

Surgical castration was performed 22 days before the beginning of confinement according to the technique described by Rabelo and Silva (2011). Post-surgery, a local dressing of larvicide and wound-healing ointment was used in addition to an antibiotic, based on long-acting oxytetracycline, which was subcutaneously applied in a single dose of $20 \mathrm{mg} / \mathrm{kg}$ of live weight. In addition, an antiinflammatory and analgesic based on meloxicam at a dose of $500 \mathrm{mg}$ for each $100 \mathrm{~kg}$ of live weight was applied intramuscularly once per day for a period of 3 days.

Immunocastration was performed with an antigonadotropin releasing factor vaccine (Zoetis, Parkville, Australia). The bulls received two subcutaneous injections of $1.0 \mathrm{ml}$ in the neck. The first and second doses were administered 22 days and 1 day before the beginning of confinement, respectively.

Homeopathic treatment was performed orally with two products (Real H Nutrição e Saúde Animal, Campo Grande, Mato Grosso do Sul, Brazil), which were pulverised and mixed with the food in the trough. The dose of first homeopathic product (Cantharis vesicatoria $10^{-400}$, Ignatiaarnara $10^{-400}$, Staphysagria $10^{-60}, \quad$ Buforana $10^{-60}$ and excipient qs $1,000 \mathrm{~g}$ ) was $40 \mathrm{~g}$ per day per animal added to the mineral supplement during the 22-day period before the beginning of confinement and added to the total diet during the 85 days of confinement; the indication was to reduce sodomy behaviour. The second product (Natrummuriaticum $10^{-60}$, 
Calcium carbonicum $10^{-30}$, Silicea terra $10^{-40}$, hypothalamus $10^{-30}$ and excipient qs $1,000 \mathrm{~g}$ ) was added to the diet during the 85 days of confinement at a dose of $100 \mathrm{~g}$ per day per bovine with the indication of improving the feed conversion and weight gain.

Animal performance and evaluation of carcass characteristics

Animals were individually weighed twice with an electronic scale. The first and last weighings occurred on the first and last days of confinement, respectively, with the animals previously subjected to a fasting period of 12 hours. Total weight gain in $\mathrm{kg}$ was determined by calculating the difference between the live final weight and the live initial weight. Carcass yield percentage was determined by dividing the weight of the warm carcass by the live weight of the animal after fasting and multiplying the result by 100 .

Two ultrasonography analyses were performed on the bulls. The first analysis occurred 20 days before the beginning of confinement, and the last analysis occurred on the last day of confinement. An ultrasound device (Aloka 500D ${ }^{\circledR}$, RibeirãoPreto, São Paulo, Brazil) and an $18-\mathrm{cm}$ probe with a frequency of $3.5 \mathrm{MHz}$ were used with a silicon standoff embedded in vegetable oil to improve the transmission of the ultrasound waves.

Rib-eye area, expressed in square centimetres $\left(\mathrm{cm}^{2}\right)$, was obtained via an ultrasound image collected transversally in the longissimus dorsi muscle in the region between the $12^{\text {th }}$ and $13^{\text {th }}$ ribs. Subcutaneous fat thickness, expressed in millimetres $(\mathrm{mm})$, was obtained between the same ribs with the probe positioned vertically to obtain a longitudinal image. Marbling, expressed as a percentage $(\%)$, was measured in the same muscle and between the same ribs.

\section{Sexual behaviour and hormonal dosage}

Visual observation of the sexual behaviour of the animals undergoing all the treatments was performed daily from $7 \mathrm{AM}$ to $6 \mathrm{PM}$ during the entire experimental period. The frequencies of sodomy or mounting, excitement indicated by penis exposure and dominance behaviour indicated by fights were annotated for each animal.

A venous blood sample of $7 \mathrm{~mL}$ was collected from each animal; the first collection was after 20 days from the beginning of confinement, and the last collection was on the last day of confinement. The blood samples were centrifuged at 2,500 RPM for 10 minutes, and the concentration of serum testosterone was determined via electrochemiluminescence using automated equipment (COBAS E 411-ROCHE ${ }^{\circledR}$, Indianapolis, United States of America) and a reagent kit with a minimum detection limit of 0.025 $\mathrm{ng} / \mathrm{mL}$ and a maximum detection limit of $15 \mathrm{ng} / \mathrm{mL}$ of testosterone.

\section{Statistical procedures}

The experimental design was completely randomised with four treatments and 13 samples each. Data consistency analyses were performed to determine the existence of outliers, normality and the homogeneity of variances. It was found that the behaviour variables required transformation to a logarithmic scale. Analysis of variance was performed, and the Tukey test was applied when the differences were significant (i.e., when $\mathrm{P}<0.05$ ). In addition to the univariate analyses, the Pearson correlation coefficient for the increase of the variables during the period of confinement was estimated. Furthermore, principal components analysis was performed by the decomposition of the correlation matrix to its eigenvalues and eigenvectors. The criterion of Kaiser (Silva and Padovani, 2006), which establishes eigenvalues greater than 1 as the criterion, was used to determine the number of components studied. All the statistical analyses were performed with the statistical software R (RProject, 2014). 


\section{Results}

There were no significant differences regarding total weight gain or carcass yield among the animals undergoing the non-castrated, immunocastrated and homeopathy treatments. However, the castrated animals had lower total weight gain and carcass yield than the remaining treatments. There was no difference in rib-eye area among treatments (Table 1).
The castrated bulls obtained a higher marbling percentage than the non-castrated and homeopathy bulls, while the immunocastrated bulls were similar to the castrated and non-castrated bulls. The homeopathy bulls had a lower marbling percentage than the immunocastrated bulls, but this characteristic was similar to the non-castrated bulls (Table 1).

Table 1. Mean values and standard deviations of total weight gain (TWG), carcass yield (CY), rib-eye area (REA), marbling and subcutaneous fat thickness (SFT) of feedlot-finished crossbred bulls treated as follows: non-castrated $(\mathrm{CON})$, surgically castrated (CAS), immunocastrated (IMU) and non-castrated treated with homeopathy (HOM).

\begin{tabular}{lcccc}
\hline \multirow{2}{*}{ Variables } & \multicolumn{4}{c}{ Treatments } \\
\cline { 2 - 5 } & Non-castrated & Castrated & Immunocastrated & $\begin{array}{l}\text { Non-castrated } \\
\text { Homeopathy }\end{array}$ \\
\hline TWG $(\mathrm{kg})$ & $160.04 \pm 20.84 \mathrm{a}$ & $128.88 \pm 20.63 \mathrm{~b}$ & $165.88 \pm 22.19 \mathrm{a}$ & $161.81 \pm 16.75 \mathrm{a}$ \\
CY $(\%)$ & $50.27 \pm 1.30 \mathrm{a}$ & $48.21 \pm 1.26 \mathrm{~b}$ & $49.71 \pm 1.26 \mathrm{a}$ & $50.19 \pm 1.21 \mathrm{a}$ \\
REA $\left(\mathrm{cm}^{2}\right)$ & $70.27 \pm 8.56 \mathrm{a}$ & $65.22 \pm 7.10 \mathrm{a}$ & $69.32 \pm 9.56 \mathrm{a}$ & $68.42 \pm 6.72 \mathrm{a}$ \\
Marbling $(\%)$ & $3.69 \pm 0.81 \mathrm{bc}$ & $4.57 \pm 0.87 \mathrm{a}$ & $3.94 \pm 0.87 \mathrm{ab}$ & $3.07 \pm 0.45 \mathrm{c}$ \\
SFT $(\mathrm{mm})$ & $3.61 \pm 0.45 \mathrm{~b}$ & $4.39 \pm 0.86 \mathrm{ab}$ & $4.90 \pm 0.84 \mathrm{a}$ & $4.28 \pm 1.30 \mathrm{ab}$ \\
\hline
\end{tabular}

Values indicated with different letters in the same row are significantly different according to the Tukey test $(P<0.05)$.

The immunocastrated bulls had a greater subcutaneous fat thickness than the non-castrated bulls; however, the subcutaneous fat thickness of the immunocastrated animals was similar to that of the castrated and homeopathy animals, and the subcutaneous fat thickness of the non-castrated animals was also similar to that of the castrated and homeopathy animals.

The castrated bulls manifested lower frequencies of mounting, excitement and dominance behaviour than did the bulls undergoing the remaining treatments. The immunocatrated bulls exhibited frequencies of mounting and excitement lower than those of the homeopathy bulls and similar to those of the non-castrated bulls (Table 2).

The homeopathy bulls manifested a greater amount of dominance behaviour than all the remaining treatments, followed by the immunocastrated and then the non-castrated bulls, and the lowest frequency of dominance behaviour was among the castrated bulls (Table 2).

At the beginning of the study, the castrated and immunocastrated bulls had a lower serum testosterone concentration than the non-castrated and homeopathy bulls; however, after 85 days, only the castrated bulls had lower serum testosterone concentrations (Table 2).

Serum testosterone concentration had a moderate positive correlation with total weight gain and carcass yield and the behaviours of mounting, excitement and dominance behaviour and a moderate negative correlation with marbling. Unexpectedly, there was no positive correlation between the difference in marbling and the difference in subcutaneous fat thickness. 
Table 2. Results of $\log _{10}$, the mean values and standard deviations $(\mathrm{M} \pm \mathrm{SD})$ of the frequencies of mounting, excitement and dominance behaviours and the mean values and standard deviations of the initial and final serum testosterone concentrations $(\mathrm{ng} / \mathrm{mL})$ of feedlot finished crossbred bulls treated as follows: non-castrated, surgically castrated, immunocastrated and non-castrated treated with homeopathy.

\begin{tabular}{llllll}
\hline \multirow{2}{*}{ Variables } & & \multicolumn{4}{c}{ Treatments } \\
\cline { 3 - 6 } & & Non-castrated & Castrated & \multicolumn{1}{c}{ Immunocastrated } & $\begin{array}{c}\text { Non-castrated } \\
\text { Homeopathy }\end{array}$ \\
\hline Mounting & $\log _{10}$ & $4.75 \mathrm{ab}$ & $3.61 \mathrm{c}$ & $4.56 \mathrm{~b}$ & $5.16 \mathrm{a}$ \\
& $\mathrm{M} \pm \mathrm{SD}$ & $159.31 \pm 172.06$ & $40.61 \pm 19.06$ & $111.08 \pm 72.87$ & $190.77 \pm 99.81$ \\
Excitement & $\log _{10}$ & $5.15 \mathrm{ab}$ & $3.61 \mathrm{c}$ & $4.84 \mathrm{~b}$ & $5.72 \mathrm{a}$ \\
& $\mathrm{M} \pm \mathrm{SD}$ & $215.15 \pm 166.04$ & $43.31 \pm 27.22$ & $142.85 \pm 73.37$ & $328.77 \pm 152.02$ \\
Dominance & $\log _{10}$ & $3.60 \mathrm{c}$ & $3.14 \mathrm{~d}$ & $4.03 \mathrm{~b}$ & $4.60 \mathrm{a}$ \\
& $\mathrm{M} \pm \mathrm{SP}$ & $40.31 \pm 18.88$ & $23.38 \pm 4.09$ & $59.31 \pm 20.72$ & $103.38 \pm 27.72$ \\
Testosterone & $\mathrm{Initial}$ & $3.71 \pm 1.77 \mathrm{a}$ & $0.03 \pm 0.00 \mathrm{~b}$ & $0.48 \pm 0.75 \mathrm{~b}$ & $2.55 \pm 2.29 \mathrm{a}$ \\
& Final & $6.96 \pm 3.87 \mathrm{a}$ & $0.02 \pm 0.00 \mathrm{~b}$ & $7.34 \pm 4.81 \mathrm{a}$ & $6.99 \pm 4.97 \mathrm{a}$ \\
\hline
\end{tabular}

Values indicated with different letters in the same row are significantly different according to the Tukey test $(P<0.05)$.

In selecting the number of components according to the criterion of Kaiser, the first two principal components were studied. In general, the eigenvectors in all the principal components had varied magnitudes resulting from a low to moderate magnitude correlation.

Considering the first principal component, most of the differences among individuals could be attributed to contrasting difference in marbling with the remaining characteristics (Table 3), in which this characteristic exhibited positive correlations with this principal component. The characteristics of a difference in the rib-eye area and a difference in the subcutaneous fat thickness had a low association with the first principal component, due to the low values of the eigenvectors. Considering the first principal component scores, there was a distinct differentiation between the castrated animals and the remaining animals. As verified by the eigenvectors, the second principal component established a contrast between the variables mounting and excitement and the remaining variables, and no well-defined groups were apparent.

Table 3. Eigenvectors of the first three principal components (PCs).

\begin{tabular}{lcc}
\hline Characteristic & PC 1 & PC 2 \\
\hline Final testosterone & $-0,325712$ & $-0,247182$ \\
Difference in marbling (DMAR) & 0,337085 & $-0,148983$ \\
Difference in rib-eye area (DREA) & $-0,182676$ & $-0,220054$ \\
Difference in subcutaneous fat thickness (DSFT) & $-0,018879$ & $-0,597208$ \\
Total weight gain (TWG) & $-0,290896$ & $-0,471871$ \\
Carcass yield (CY) & $-0,308931$ & $-0,242341$ \\
Mounting & $-0,423036$ & 0,361419 \\
Excitement & $-0,466535$ & 0,315263 \\
Dominance & $-0,412171$ & $-0,014750$ \\
\hline
\end{tabular}

To determine the number of components studied, was used eigenvalues greater than 1 


\section{Discussion}

The low total weight gain and carcass yield of castrated bulls in comparison with the remaining treatments can be explained by the absence of the anabolising effect of testosterone, as reported by Freitas et al. (2008). The total weight gain and the carcass yield of the castrated bulls were approximately $26 \%$ and $3.80 \%$ lower, respectively, than the mean values of these parameters for the bulls undergoing the remaining treatments.

The better performance of the non-castrated animals compared with the castrated animals observed in this study is consistent with the results of Zhou et al. (2011). These authors analysed feedlot finished Simental calves, including non-castrated animals and animals castrated at 2 months of age that were slaughtered at 22 months of age, and concluded that the non-castrated calves obtained higher total weight gain and rib-eye area values and that the castrated calves obtained a better carcass finish with a higher fat deposition in marbling and subcutaneous fat thickness. Marti et al. (2013) concluded that feedlot-finished Holstein calves castrated at 3 and 8 months of age and slaughtered at 10 and 14 months of age had lower slaughter weights than non-castrated animals and a better carcass finish when slaughtered at 14 months of age.

The immunocastrated bulls were expected to display behaviours similar to those of the castrated animals. However, this was not observed in this study because the performance of the immunocastrated animals was similar to that of the non-castrated animals and superior to that of the castrated animals, most likely due to the increase in the serum testosterone concentration of the immunocastrated animals during the 85 days of confinement. The increase in serum testosterone concentration indicates that the vaccine was incapable of maintaining low testosterone levels in these animals during the experimental period, most likely due to a decrease in the production of anti-GnRH antibodies by some immunosuppressor effect, as cited by Yousef et al. (2013).
The result regarding the performance of the immunocastrated bulls is consistent with the observations of Amatayakul-Chantler et al. (2013), who compared the performance of Bos taurus indicus in a grazing regime. In that study, the animals were surgically castrated at 23 months of age or immunocastrated with two doses of the vaccine at 20 and 23 months of age, and all the animals were slaughtered at 30 months of age; it was concluded that the immunocastrated animals obtained a higher total weight gain and better carcass yield.

The performance characteristics of the immunocastrated bulls in this study are contrary to the results of Zanella et al. (2009), who compared non-castrated and immunocastrated bulls and concluded that non-castrated Nelore bulls, with breeding and finishing in a grazing regime, had a higher weight gain but a diminished carcass finish compared with the immunocastrated animals.

The lower serum testosterone levels of the immunocastrated bull sat the beginning of confinement may have contributed to the high subcutaneous fat thickness of the immunocastrated bulls compared with the non-castrated bulls. This result is consistent with that of Amatayakul-Chantler et al. (2012), who evaluated the crossbreeding of Bos taurus indicus with Brown Swiss in a feedlot and concluded that immunocastrated animals provided a better carcass quality than non-castrated animals.

The caloric content of the diet and the genetic group of the animals are correlated with the finish degree of the animals, enabling higher levels of subcutaneous fat deposition and marbling in cattle (LAGE et al., 2012). In this study, a genetic group of late-finishing animals and a diet with a lower caloric content were used. This explains the fact that there was no difference in subcutaneous fat thickness between the non-castrated and castrated animals and in the marbling between the noncastrated and immunocastrated animals, in contrast to the results of Amatayakul-Chantler et al. (2012), who concluded that meat quality in terms of fat deposition of immunocastrated animals was higher than that of non-castrated animals. 
The castrated animals had superior marbling than the non-castrated and homeopathy bulls due to the increase in marbling that occurs in the absence of the effect of testosterone. Marbling and subcutaneous fat thickness are affected by age, breed, food type and sexual condition. Castrated animals deposit fat more easily, and the finishing diet promotes a better carcass finish because the diet has more calories (RESTLE et al., 2000).

In this study, marbling had a non-significant correlation with subcutaneous fat thickness. However, fat tissue is the last to be deposited, and fat accumulation in muscles increases with the maturity of the animals; fat deposition begins with subcutaneous fat, and the increase of subcutaneous fat invariably and positively affects the accumulation of intramuscular fat or marbling (BRUNS et al., 2004). The possible reasons for the non-significance of the correlation between marbling and subcutaneous fat thickness may be the insufficient confinement period, the lower caloric content of the diet and the level of blood in the dairy cattle leading to inefficient fat deposition.

The frequencies of mounting, excitement, dominance behaviour were lower for the castrated animals than for those of the remaining treatments. The immunocastrated animals did not exhibit reduced sodomy behaviour or excitement compared with the non-castrated animals, similar to the results of de Price et al. (2003), who concluded that immunocastrated and confined Angus and Hereford bulls display the same sexual behaviour as non-castrated animals. However, Jago et al. (1997) evaluated the effect of the immunocastration vaccine in prepubescent calves and concluded that the vaccine delayed puberty, sexual development and aggressive behaviour.

The results obtained for sexual behaviour and dominance of the immunocastrated animals may be explained by the increase in the final testosterone concentrations in the immunocastrated animals, which were at levels similar to those of the non- castrated animals. This finding is in contrast to the results of Albrecht et al. (2012), in which there was a decrease in the testosterone concentration and the inhibition of animal behaviours.

This study demonstrated the correlation between testosterone and the frequencies of mounting, excitement, dominance behaviour. The hormonal influence of testosterone may have been the trigger for sodomy because there was little activity of mounting and excitement in the castrated animals.

However, according to Malafaia et al. (2011), aggressive interactions and sodomy may originate from being idle and other factors, such as a grouping with dominance hierarchy, confinement with a high population density and the violation of individual space, that are associated with environmental factors such as thermal stress and the absence of shade; these factors could have contributed secondarily to the frequency of mounting, excitement, dominance behaviour of the animals.

Over the 85 days of the experiment, there was an increase in the serum testosterone concentrations in the immunocastrated animals. However, Janett et al. (2012a, 2012b) observed a decrease in the testosterone concentration after a booster of the vaccine, maintaining a low level until at least 22 weeks, in immunocastrated Holstein calves both between 3 and 6 weeks of age and between 6 and 7 months of age. The older age of the animals used in this study may have imposed a higher challenge to the vaccine. Additionally, an immunosuppressive factor may have occurred, for example, the environmental stress of confinement, which could lead to an increase in testosterone or a decrease in anti-GnRH antibodies.

The homeopathy animals did not exhibit a reduced frequency of mounting, excitement, dominance behaviour and did not have better performance than the non-castrated animals, in contrast to the results of Souza (2002), who suggested that homeopathy is indicated for the improvement of weight gain and for the reduction of sodomy. The scientific literature 
seems to be lacking and contradictory regarding the use of homeopathy in cattle with the aim of improving animal performance and behaviour.

Ribeiro et al. (2011) evaluated the efficacy of a homeopathic product in confined Nelore and Tabapuã breeds and concluded that homeopathy provided an increase of $17 \%$ in the mean daily weight gain and a decrease of $41 \%$ in the feed conversion compared with the control group, in the last 28 days of confinement. However, Ítavo et al. (2010) compared the performance of 18-monthold Brangus breeds in confinement that received homeopathic products in the finishing phase and concluded that the use of homeopathy did not provide a better performance than that of the control group. The diversity of homeopathic products is believed to be one of the reasons for the discrepancy among the results of studies on this topic.

The first principal component clearly indicates the differentiation of the behaviours of the castrated animals from those of the remaining treatments. The differentiation of marbling from the remaining components may be due to the absence of the anabolising effect of testosterone in these animals, which leads to a higher fat deposition and lower frequencies of mounting, excitement, dominance behaviour and can also explain the lower total weight gain and carcass yield.

The second principal component was not as well defined as the first principal component and indicated a contrast between the mounting and excitement characteristics and the remaining characteristics. The second principal component may be determined by specific individual variations, and the identification of defined groups for this principal component was not possible.

\section{Conclusion}

The immunocastrated bulls had a productive performance similar to that of the non-castrated bulls and a carcass finish similar to that of the castrated bulls. However, the castrated bulls had a lower productive performance than bulls that underwent the remaining treatments. The homeopathic treatment resulted in a performance and carcass finish similar to those with non-castration.

Immunocastration did not efficiently maintain low testosterone levels over the 85 days of this study. Homeopathy and immunocastration did not mitigate the behaviours of sodomy and dominance.

\section{Acknowledgments}

Special thanks are given to the Instituto Federal de Educação, Ciência e Tecnologia Goiano, employees and business partners on the project.

\section{References}

ALBRECHT, A. K.; BEILAGE, E. G.; KANITZ, E.; PUPPE, B.; TRAULSEN, I.; KRIETER, J. Influence of immunisation against GnRF on agonistic and mounting behaviour, serum testosterone concentration and body weight in male pigs compared with boars and barrows. Applied Animal Behaviour Science, Amsterdam, v. 138, n. 1-2, p. 28-35, 2012.

AMATAYAKUL-CHANTLER, S.; HOE, F.; JACKSON, J. A.; ROCA, R. O.; STEGNER, J. E.; KING, V.; HOWARD, R.; LOPEZ, E.; WALKER, J. Effects on performance and carcass and meat quality attributes following immunocastration with the gonadotropin releasing factor vaccine Bopriva or surgical castration of Bos indicusbulls raised on pasture in Brazil. Meat Science, Champaign, v. 95, n. 1, p. 78-84, 2013.

AMATAYAKUL-CHANTLER, S.; JACKSON, J. A.; STEGNER, J.; KING, V.; RUBIO, L. M. S.; HOWARD, R.; LOPEZ, E.; WALKER, J. Immunocastration of Bos indicus $x$ Brown Swiss bulls in feedlot with gonadotropinreleasing hormone vaccine Bopriva provides improved performance and meat quality. Journal of Animal Science, Champaign, v. 90, n. 11, p. 3718-3728, 2012.

ASSOCIATION OF OFFICIAL ANALYTICAL CHEMISTS - AOAC. Official methods of analysis. 16. ed. Washington: D.C., 1995. 1094 p.

BRUNS, K. W.; PRITCHARD, R. H.; BOGGS, D. L. The relationships among body weight, body composition, and intramuscular fat content in steers. Journal of Animal Science, Champaign, v. 82, n. 5, p. 1315-1322, 2004. 
COETZEE, J. F.; NUTSCH, A. L.; BARBUR, L. A.; BRADBRUN, R. M. A survey of castration methods and associated livestock management practices performed by bovine veterinarians in the United States. $B M C$ Veterinary Research, London, v. 6, n. 12, p. 1-19, 2010.

FREITAS, A. K.; RESTLE, J.; PACHECO, P. S.; PADUA, J. T.; LAGE, M. E.; MIYAGI, E. S.; SILVA, G. F. R. Características de carcaças de bovinos nelore inteiros vs castrados em duas idades, terminados em confinamento. Revista Brasileira de Zootecnia, Viçosa, MG, v. 37, n. 6, p. 1055-1102, 2008.

ÍTAVO, L. C. V.; DIAS, A. M.; ÍTAVO, C. C. B. F.; OTTONI, A. L.; MORAIS, M. G.; TORRES JÚNIOR, R. A. A. Homeopatia na terminação de novilhos em confinamento. Archivos de Zootecnia, Córdoba, v. 59, n. 226, p. 225-232, 2010.

JAGO, J. G.; BASS, J. J.; MATTHEWS, L. R. Evaluation of a vaccine to control bull behaviour. Proceedings of the New Zealand Society of Animal Production, Napier, v. 57, p. 91-95, 1997.

JANETT, F.; GERIG, T.; TSCHUOR, A. C.; AMATAYAKUL-CHANTLER, S.; WALKER, J.; HOWARD, R.; BOLLWEIN, H.; THUN, R. Vaccination against gonadotropin-releasing factor (GnRF) with Bopriva significantly decreases testicular development, serum testosterone levels and physical activity in pubertal bulls. Theriogenology, Stoneham, v. 78, n. 1, p. 182-188, 2012 b.

JANETT, F.; GERIG, T.; TSCHUOR, A. C.; AMATAYAKUL-CHANTLER, S.; WALKER, J.; HOWARD, R.; PIECHOTTA, M.; BOLLWEIN, H.; HARTNACK, S.; THUN, R. Effect of vaccination against gonadotropin-releasing factor (GnRF) with Bopriva ${ }^{\circledR}$ in the prepubertal bull calf. Animal Reproduction Science, Amsterdam, v. 131, n. 1-2, p. 72-80, 2012a.

LAGE, J. F.; PAULINO, P. V. R.; VALADARES FILHO, S. C.; SOUZA, E. J. O.; DUARTE, M. S.; BENEDETI, P. D. B.; SOUZA, N. K. P.; COX, R. B. Influence of genetic type and level of concentrate in the finishing diet on carcass and meat quality traits in beef heifers. Meat Science, Champaign, v. 90, n. 3, p. 770-774, 2012.

MALAFAIA, P.; BARBOSA, J. D.; TOKARNIA, C. H.; OLIVEIRA, C. M. C. Distúrbios comportamentais em ruminantes não associados a doenças: origem, significado e importância. Pesquisa Veterinária Brasileira, Rio de Janeiro, v. 31, n. 9, p. 781-790, 2011.

MARTI, S.; REALINI, C. E.; BACH, A.; PÉREZ-JUAN, M.; DEVANT, M. Effect of castration and slaughter age on performance, carcass, and meat quality traits of Holstein calves fed a high-concentrate diet. Journal of Animal Science, Champaign, v. 91, n. 3, p. 1129-1140, 2013.
PRICE, E. O.; ADAMS, T. E.; HUXSOLL, C. C.; BORGWARDT, R. E. Aggressive behavior is reduced in bulls actively immunized against gonadotropin-releasing hormone. Journal of Animal Science, Champaign, v. 81, n. 2, p. 411-415, 2003.

R DEVELOPMENT CORE TEAM. A language and environment forstatistical computing. Vienna: R: Foundation for Statistical Computing, 2014. Available at: <http://www.R-project.org/>. Accessed: 15 feb. 2014.

RABELO, R. E.; SILVA, O. C. Aspectos morfofuncionais, clínicos e cirúrgicos do pênis, prepúcio e testículos de touros. Goiânia: Kelps, 2011. 212 p.

RESTLE, J.; VAZ, F. N.; FEIJÓ, G. L. D.; BRONDANI, I. L.; ALVES FILHO, D. C.; BERNARDES, R. A. C.; FATURI, C.; PACHECO, O. S. Características de carcaça de bovinos de corte inteiros ou castrados de diferentes composições raciais Charolês x Nelore. Revista Brasileira de Zootecnia, Viçosa, MG, v. 29, n. 5, p. 1371-1379, 2000.

RIBEIRO, J. S.; GONÇALVES, T. M.; MACHADO NETO, O. R.; CAMPOS, F. R.; FARIA, W. L. Homeopatia na terminação de novilhos nelores e tabapuãs confinados. Agropecuária Científica no Semi-Árido, Patos, v. 7, n. 1, p. 38-44, 2011.

SILVA, N. R.; PADOVANI, C. R. Utilização de componentes principais em experimentação agronômica. Energia Agrícola, Botucatu, v. 21, n. 4, p. 98-113, 2006.

SOUZA, M. F. A. Homeopatia veterinária. In: CONFERÊNCIA VIRTUAL GLOBAL SOBRE PRODUÇÃO ORGÂNICA DE BOVINOS DE CORTE, 1., 2002, São Paulo. Proccedings... São Paulo: Editora: Embrapa, 2002. Available at: <http:www.cpap.embrapa. br/agencia/congressovirtual/pdf/ portugues/02pt02.pdf $>$. Accessed at: 10 feb. 2014.

YOUSEF, M. R.; MAHMOUD, M. A. E. F.; ALI, S. M.; AL-BLOWI, M. H. Seroprevalence of some bovine viral respiratory diseases among non-vaccinated cattle in Saudi Arabia. Veterinary World, Rajkot, v. 6, n. 1, p. 1-4, 2013.

ZANELLA, R.; ZANELLA, E. L.; REEVES, J. J.; HERNANDEZ, J.; MOTTA, A. C.; AVILA, D. Características testiculares de touros imunizados com vacina anti-hormônio liberador do hormônio luteinizante. Pesquisa Agropecuária Brasileira, Brasília, v. 44, n. 10, p. 1359-1363, 2009.

ZHOU, Z. K.; GAO, X.; LI, J. Y.; CHEN, J. B.; XU, S. $Z$. Effect of castration on carcass quality and differential gene expression of longissimus muscle between steer and bull. Molecular Biology Reports, Basel, v. 38, n. 8, p. 5307-5312, 2011. 